\title{
Transcriptional Activator Myb
}

National Cancer Institute

\section{Source}

National Cancer Institute. Transcriptional Activator Myb. NCI Thesaurus. Code C17329.

Transcriptional activator Myb (636 aa, $\sim 71 \mathrm{kDa}$ ) is encoded by the human MYB gene.

This protein plays a role in transcriptional activation and the regulation of both

proliferation and differentiation of hematopoietic cells. 